\title{
TARI TABUT SEBAGAI MANIFESTASI BUDAYA MASYARAKAT KOTA BENGKULU
}

\author{
Syielvi Dwi Febrianty ${ }^{1}$, Asril, dan Erlinda \\ ${ }^{1}$ Minat Studi Pengkajian Seni Tari Program Pascasarjana Institut Seni Indonesia Padangpanjang \\ Email : Syielvidwifebrianti@gmail.com, Hp: 081363411320
}

\begin{abstract}
This research aims at discussing Tabut dance as the cultural manifestation of Bengkulu people. Tabut dance is a creation dance sourced from Tabut ritual, namely a ritual sourced from Syiah Islam, but it has grown and developed into the typical culture of Bengkulu people. Various rituals in Tabut were symbolically arranged into a new dance namely Tabut dance. This Tabut dance is perfomed every year in Tabut celebration and several other big events whether it's inside the Bengkulu city or outside the city. This research is a qualitative research with descriptive and analytical natures. Result achieved in this research is that Tabut dance is the cultural manifestation of Bengkulu people based on the rituals existing on Tabut ritual that is than actualized into a creation dance.
\end{abstract}

Keywords: Tabut dance, Tabut ritual, cultural manifestation, Bengkulu people.

\begin{abstract}
ABSTRAK
Penelitian ini bertujuan untuk membahas tari Tabut sebagai manifestasi budayamasyarakat Kota Bengkulu. Tari Tabut merupakan tari kreasi yang bersumber dariritual Tabut, yaitu suatu ritual yang berasal dari Islam Syiah, tetapi telah tumbuhdan berkembang menjadi budaya khas masyarakat Kota Bengkulu. Berbagai ritusyang ada di dalam Tabut ditata secara simbolik menjadi tarian baru, yaitu tari Tabut. TariTabut ini ditampilkan setiap tahunnya dalam perayaan Tabut dan beberapa eventbesar lainnya baik di dalam maupun di luar Kota Bengkulu. Penelitian ini adalahpenelitian kualitatif yang bersifat deskriptif dan analisis. Hasil yang dicapai dalam penelitian ini adalahbahwa tari Tabut merupakan menifestasi budaya masyarakat Kota Bengkulu yangberakar dari ritus-ritus yang ada pada ritual Tabut yang diwujudkan dalam bentuktarian kreasi.
\end{abstract}

Kata Kunci: Tari Tabut, ritual Tabut, manifestasi budaya, masyarakat Kota Bengkulu.

\section{PENDAHULUAN}

Tabut adalah sebuah upacara keagamaan bagi penganut Syiah untuk mengenang kematian Husein di Karbala, pada tanggal 10 Muharam 61 Hijriah (10 Oktober 680 M). Tradisi Tabut ini dibawa dari Irak ke Selatan Asia oleh orang India. Kemudian tradisi ini dibawa dari India ke Bengkulu oleh para muslim India pada tahun 1336 M (A. Syiafril Sy, 2012: 13). Seiring dengan perjalanan waktu orang Syiah merayakan ritual Tabut sebagai upacara keagamaan, sedangkan orang Bengkulu merayakannya sebagai upacara 
budaya yang kemudian diklaim oleh orang Bengkulu sebagai warisan budaya mereka, karena telah berubah menjadi festival budaya masyarakat Bengkulu. Dalam kasus ini, unsur keagamaan dalam upacara tersebut telah berkurang, sementara unsur budaya etnis Bengkulu menjadi semakin kuat. Hingga kini Tabut sendiri sudah menjadi budaya tradisi tahunan masyarakat Kota Bengkulu.

Seiring dengan perkembangan zaman ritual Tabut di Bengkulu mengalami proses yang tidak hanya sebagai ritual budaya semata. Agar ritual ini tetap lestari perlu disiapkan sebuah strategi kebudayaan yang mampu mencermati, memprediksi, dan menyikapi perkembangan budaya Tabut. Strategi tersebut diwujudkan kedalam festival tahunan dengan nama festival Tabut yang biasanya digelar added event sebagai daya tarik wisatawan. Maka, berbagai seni tontonan atraksi budaya semacam musikdol, telong-telong, ikan-ikan, dan tari Tabut digelarsebagai hiburan melekat dalam rangkaian ritual Tabut. Kondisi tersebut memunculkan gagasan dan ide untuk mewujudkan budaya Tabut dalam bentuk garapan seni pertunjukan salah satunya adalah tari Tabut kreasi.

Tari Tabut adalah tari kreasi yang diciptakan sekitar tahun 1987. Tari ini terinspirasi dari ritual Tabut sebagai sebuah peristiwa budaya tradisi Kota Bengkulu. Isian dan bentuk pertunjukan tari Tabut terinspirasi dari proses ritual Tabut yang dikelompokkan menjadi 10 ritusseperti doa keselamatan, ambik tanah, duduk penja, malam menjara, meradai, arak penja, arak seroban, hari gam, tabut naik pangkek, arak gedang, soja, tabut tebuang, dan menyuci penja.Selain itu, gerak tari Tabut adalah pengembangan dari tari tradisi Bengkulu, yaitu tujuh tari yang terdapat dalam Bimbang Gedang. Tari Tabut memiliki ciri khas menggunakan properti jari-jari, cokicoki, dan miniatur Tabut. selain itu, musik yang dipakai untuk iringan Tabut juga wajib digunakan pada tari ini. Tari Tabut selain mengandung unsur budaya Bengkulu juga mengandung estetika yang tinggi. Estetika tidak hanya pada manifestasi yang tampak pada mata. Pandangan bahwa estetika hanya mengkaji segala sesuatu yang indah (cantik dan gaya seni) telah lama dikoreksi, karena terdapat kecenderungan karya-karya seni modern tidak lagi menawarkan kecantikan, akan tetapi lebih kearah makna dan aksi mental (Rosi Afriyanti, 2019: 203). Selain menambah nilai baru yang mengandung unsur budaya dan estetika yang tinggi, tujuan terwujudnya tari ini merupakan bentuk kontribusi terhadap budaya Tabut yang telah mentradisi. Alasan awal kenapa tari ini diciptakan adalah karena rasa ingin mengenalkan budaya Tabut melalui tarian. (Syukri,wawancara, 7 Februari 2018).

Ketertarikan penulis dalam penelitian ini, yaitu kehadiran tari Tabut kreasi sebagai manifestasi budaya masyarakat Kota Bengkulu merupakan bentuk budaya tradisi serta kreativitas pemikiran baru yang menjadi identitas dalam menambah suatu nilai di masyarakatnya. Ide-ide dan pemikiran yang dihasilkan dari produk budaya yang sudah ada sebelumnya dimanifestasikan dalam bentuk nyata sesuai mengikuti zaman. Budaya itu akan terus bertahan, tetapi berubah mengikuti sesuai perkembangan zaman. Perlu siasat dalam menyikapi perkembangan zaman dan perlu adanya pandangan 
yang jauh ke depan untuk terus memperbarui budaya, namun tidak mengubah ketentuan dan isi, tetapi dalam bentuk kemasan baru.

\section{STUDI LITERATUR}

Studi literatur ini dimaksudkan untuk mengungkapkan berbagai teoriteori yang relavan dengan permasalahan yang sedang diteliti. Teknik ini dilakukan dengan cara membaca, mempelajari dan mengkaji literatur-literatur yang berhubungan dengan tari Tabut sebagai pembanding dalam penulisan ini. Tulisan mengenai deskripsi penyelanggaraan tabut ditulis oleh Ahmad Syiafril Sy (2012) Tabut Karbela Bencoolen dari Punjab. Tulisan ini memberikan informasi tentang keberadaan budaya Tabut yang telah menjadi budaya tradisi masyarakat Bengkulu, dan memberikan informasi tentang perjalanan Tabut hingga sampai ke Bengkulu. Tulisan ini juga menjelaskan tahapan ritual Tabut serta pesan moral yang terkandung di dalamnya, dan juga membahas permainan ikan-ikan, musik Dol dan tarian berirama Tabut yang terinspirasi dari gerakan-gerakan ritual Tabut pada malam menjara.

Harapandi Dahri (2009) dalam bukunya yang berjudul, Tabot Jejak Cinta Nabi di Bengkulu.Buku ini membahas tentang kebudayaan tradisi Tabut dan akulturasi budaya Bengkulu serta kebersatuan masyarakat, mengenal para tokoh inisiator dan kreator Tabut. Tulisan ini juga membahas proses transformasi dan akomodasi budaya dalam tradisi Tabut serta Tabut sebagai kemasan budaya. Pada bagian belakang tulisan ini membahas keunikan seni tari kreasi Tabut yang dibawakan oleh Keluarga Kerukunan Tabut, dan tarian ini wajib ditampilkan pada setiap kali perayaan Tabut

Artikel Ria Twin Sepiolita (2017) dengan judul "Ritual Mengambik Tanah Dalam Upacara Tabut". Tulisan ini membahas tentang proses mengambik tanah yang merupakan kegiatan utama dalam ritual Tabut. Mengambik tanah yang bermakna mengingatkan asal mula manusia dari tanah dan akan kembali ke tanah. Tulisan ini juga menjelaskan tahapan mengambik tanah, bentuk pertunjukan mengambik tanah, dan aspek yang mendukungnya.

Artikel Pesona Renta (2011) dengan judul, "Tabot: Upacara Tradisi Masyarakat Pesisir Bengkulu."Tulisan ini menjelaskan tentang Tabut, sejarah Tabut, pembuatan Tabut, nilai-nilai yang terkandung di dalam ritual Tabut, rangakaian upacara Tabut, serta membahas Tabut dan masyarakat Bengkulu, tetapi di dalam tulisan ini tidak ditemukan tulisan mengenai tari yang berirama Tabut.

Artikel Asril (2013) dengan judul, "Perayaan Tabuik dan Tabot: Jejak Ritual Keagamaan Islam Syiah di Pesisir Barat Sumatra". Tulisan ini membahas tentang asal-usul perayaan Tabuik dan Tabot di Sumatra yang mendapat pengaruh dari ritual keagamaan kaum Syiah di Persia (Iran). Tulisan ini juga membahas perubahan nilai ritual menjadi ritual budaya, bahkan menjadi pertunjukan budaya saja.

\section{METODE PENELITIAN}

Penelitian ini adalah penelitian kualitatif yang menghasilkan data deskriptif, yaitumemberikan gambaran secara sistematis atau teratur tentang pokok persoalan.Persoalan yang dimaksud di sini adalah mengenai tari Tabut 
sebagai

manifestasibudaya

masyarakat Kota Bengkulu.

Pengumpulan data yang terkait

denganpermasalahan penelitian

dilakukan melalui studi pustaka dan studi lapangan. Studilapangan menjadi bagian yang sangat penting dalam pengumpulan data yangterkait dengan material budaya Kota Bengkulu dan unsur-unsur ritus Tabut yangdigarap menjadi materi pokok dalam karya tari Tabut. Pengumpulan data dilapangan dilakukan melalui wawancara dengan berbagai narasumber, pengamatanlangsung pertunjukan tari Tabut dalam konteks upacara Tabut, khususnya dalamfestival Tabut, pendokumentasian, dan beberapa dokumen pertunjukan tari Tabut,seperti foto dan video. Wawancara dilakukan dengan para seniman yang terlibatdalam tari Tabut dan ke beberapa sanggar yang ada di Bengkulu dan tokohmasyarakat untuk mendapatkan data yang terkait dengan unsur-unsur budayamasyarakat Kota Bengkulu dan unsur-unsur ritual Tabut yang digarap pada tariTabut. Lokasi penelitian di Kampung Bali Bengkulu tempat pertunjukan tari Tabut ditampilkan dan di beberapa tempat di Kota Bengkulu.

\section{PEMBAHASAN}

\subsection{Tari Tabut sebagai Kreasi dari Ritual Tabut}

Tari Tabut diciptakan pada tahun 1987 oleh Dindin yang merupakan seniman tari yang ada di Bengkulu. Dindin bersama rekanrekan yang tergabung dalam kelompok Artistika mencoba menggarap ritual Tabut 1-10 Muharam menjadi sebuah tari.Tari
Tabut terinspirasi dari ritualTabut yang berasal dari ritual Syiah yang telah menjadi budaya khas masyarakat Kota Bengkulu. Ritual Tabut diadakan setiap tahun pada setiap awal bulanMuharam yang diselenggarakan oleh Pemerintah Daerah Kota Bengkulu. Gagasan penciptaan tari Tabut adalah salah satu upaya ingin mengenalkan budaya Tabut melalui tarian.

Setelah tari ini diciptakan, tari ini ditampilkan pada acara festival tari Indonesia di Istana Negara pada tahun 1987 dan mendapat apresiasi yang sangat luar biasa karena menampilkan tari berceritakan tentang ritual Tabut yang diiringi dengan musik dol, yaitu merupakan alat musik tradisi Bengkulu yang biasa digunakan dalam ritual Tabut. Sejak diresmikan festival Tabut tahun 1992, maka penampilan tari Tabut dan musik kreasi dol dapat dikatakan sudah menjadi kebutuhan dalam setiap upacara Tabut, karena masuk ke dalam bagian ritual yang diadakan dari 1-10 Muharam.

Tari yang sudah menjadi tuntutan setiap tahunnya dalam festival budaya tahunan menjadikan tari Tabut terus berkembang. Dalam perkembangannya sehingga lahirlah beberapa tari Tabut yang digarap dengan dasar keilmuan tari oleh para akademisi yang paham akan tari. Selain itu, pertunjukan tari Tabut kreasi berkembang menjadi festival tahunan dengan lomba yang diwadahi pemerintah setiap tahunnya. Hal ini membuat seniman tari dan sanggarsanggar yang ada di Bengkulu berpacu dalam menciptakan tari-tari kreasi Tabut yang bersumberkan dari ritusritus yang ada pada ritual Tabut.

Gerak-gerak tari Tabut adalah pengembangan dari gerakan tari tradisi Bimbang Gedang yang ada di 
Kota Bengkulu. Lebih tepatnya gerak tari Tabut juga merupakan pengembangan dari tujuh tari yang ada di Bimbang Gedang,sehingga tari kreasi ini tetap berpijak pada unsur tradisi Bengkulu. (Dindin, wawancara29 Mei 2020 di Bengkulu). Gerak-gerak tersebut dikembangkan menjadi gerak-gerak baru, tetapi tetap menggambarkan ritus-ritus yang ada pada Tabut. Ritus-ritus yang terdapat dalam ritual Tabut,yaitu: Doa keselamatan, ambik tanah, duduk penja, malammenjara, meradai, arak penja, arak seroban, hari gam, Tabutnaik pangkek, arak gedang, soja, tabut tebuang, menyucipenja. Upacara ini bertujuan untuk mengenang matinya Husein Bin Ali diKarbala. Tradisi berkabung ini telah mengalami asimilasi dan akulturasi dengan budaya setempat, diwariskan, dan dilembagakan menjadi upacara Tabut.

Menurut Rustam Efendi, selaku seniman, budayawan, dan Keturunan Keluarga Tabut (KKT) mengatakan beberapa kelompok KKT atau sanggar yang ada di Bengkulu juga menggunakan gerak dalam tari Tabut yang terdapat pada malam menjara, yaitu gerak uli (joget). Biasanya para pemusik secara spontan melakukan gerak loncat kaki secara bergantian diikuti gerak kedua tangan di atas kepala mengikuti alunan musik doldengan pola irama tamatam. Pola irama tamatam dari dol menggambarkan suasana riang. Riang yang dimaksud adalah penggambaran genderang semangat perang di Padang Karbala. (Rustam Efendi, wawancara22 januari 2018di Bengkulu).

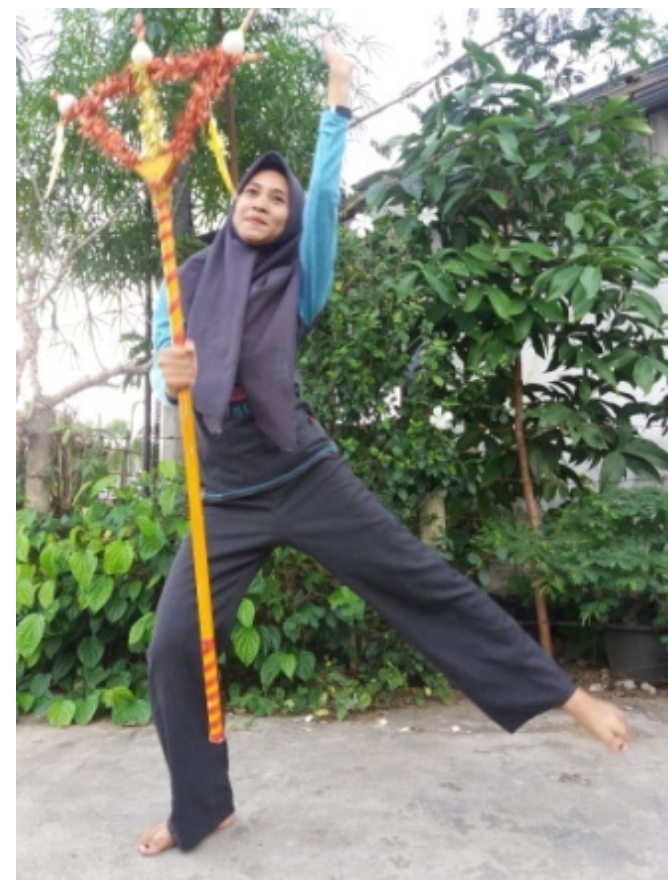

Gambar 1

Gerak loncat dengan pola musik tamatam yang terdapat pada malam Menjara sebagai salah satu ritual Tabut (gerak uli)

(Dokumentasi: Syielvi Dwi Febrianti, Sanggar Jessica Bengkulu,18 Februari 2018)

\section{Busana}

Busana yang digunakan merupakan pengembangan dari busana adat Bengkulu, yaitu baju dan celana panjang berdasarkan syariat Islam, bagian pinggang menggunakan ornamen dari rumbai yang merupakan pengembangan ornamen Bengkulu pucuk rebung. Bagian kepala menggunakan kreasi bentuk Tabut. Untuk baju laki-laki menggunakan baju Melayu dan detar yang merupakan perpaduan unsur budaya Bengkulu. Seiring perkembangan zaman, kreasi-kreasi baju dan hiasan kepala semakin beragam dan berwarna. 


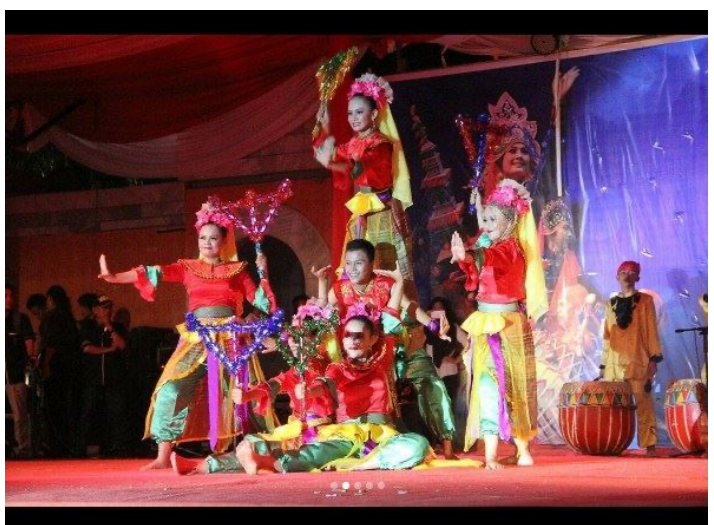

Gambar 2.

Kostum pada bagian pinggang menggunakan ornamen dari rumbai yang merupakan pengembangan ornamen Bengkulu pucuk rebungdalam festival Tabut 2013.(www.sittibeybe.blogspot.com)

\section{Properti}

Selain busana properti juga menjadi ciri khas dalam tari Tabut. Ada tiga properti yang menjadi ciri khas, yaitu jari-jari, coki-coki, dan miniatur Tabut. Ketika properti ini hadir dalam tari Tabut kreasi sudah menjadi simbol ciri dari tari Tabut Bengkulu. Inilah yang membedakan tari Tabut dengan tari kreasi lainnya. Selain properti yang menjadi ciri khas lainnya adalah musik pendukung menggunakan alat musik tradisi Bengkulu, yaitu doldengan menggunakan pola irama tamatam, swena, dan sweri. Alat musik yang harus digunakan untuk mengiringi tari ini adalah dol, tasa, klentengan besi (kulintang), dan suling.

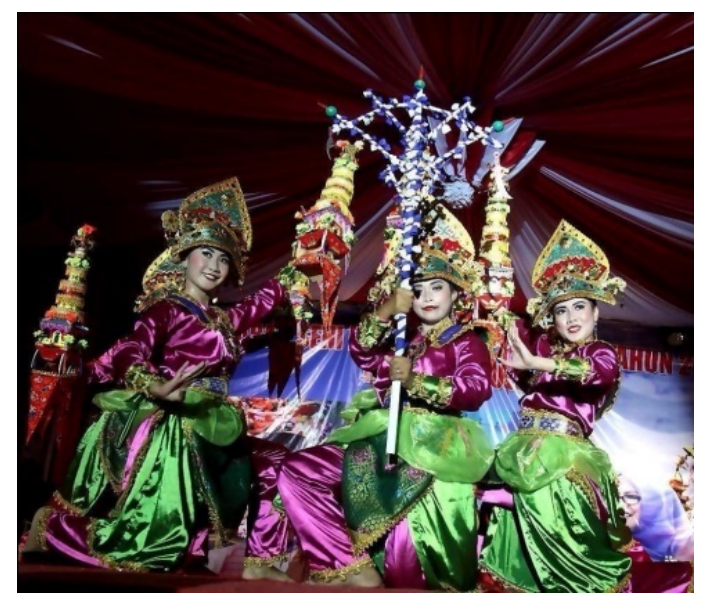

Gambar 3

Penggunaan properti jari-jari dan miniatur tabut

(Repro by Syielvi Dwi Febrianti 2018)

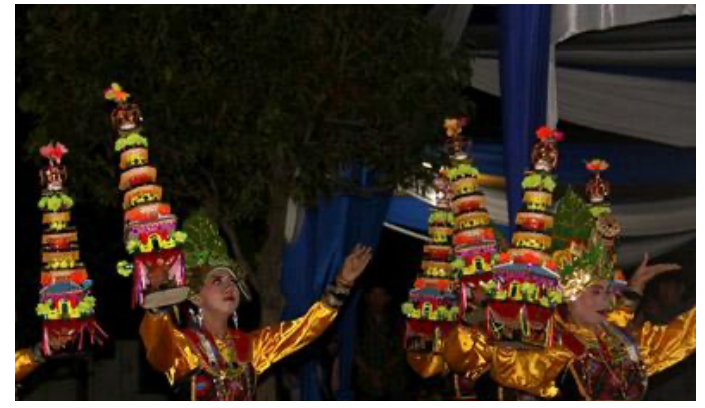

Gambar 4

Properti tari yang menyerupai tabut dalam bentuk miniatur yang bermaknasebagai simbol Tabut pada festival Tabut 2016 (www.Indonesiakaya.blogspot.com)

\section{Penari}

Penari tari Tabut pertama kali terdiri dari tujuh orang perempuan, dan tujuh orang penari laki-laki. Lakilaki dalam tari ini lebih berperan membawa properti seperti coki-coki dan miniatur Tabut. Seiring dengan perkembangan zaman jumlah penari tari Tabut menyesuaikan kebutuhan garapan diatas pentas sesuai keinginan koreografer. Seringkali pemusik juga ikut menjadi penari dalam membawa properti, dimana musik bukan hanya sekadar pengiring tari, tetapi musik ikut di dalam tari Tabut. 


\subsection{Tari Tabut Sebagai Manifetasi Budaya Masyarakat Kota Bengkulu}

Manifestasi budaya merupakan aturan dalam masyarakat yang sudah kompleks atau berupa cita-cita yang sudah dirumuskan orang-orang yang arif di dalam masyarakat. Manifestasi budaya juga merupakan pola-pola tindakan yang aktual dalam suatu masyarakat. Tindakan aktual tersebut dinyatakan ke dalam bentuk sebuah produk yang telah dikemas dan dapat dilihat wujudnya. Tari Tabut sebagai manifestasi budaya Tabut adalah suatu prinsip yang diturunkan dari keputusan bersama masyarakat Bengkulu dalam menemukan suatu perkembangan dan cara dalam memperkenalkan budaya melalui bentuk tari yang mengadung estetika dan mencirikan budaya masyarakat Kota Bengkulu.

Budaya adalah cara hidup yang dapat berkembang secara bersama dalam suatu kelompok masyarakat secara turun temurun dari satu generasi kegenerasi berikutnya di mana budaya terbentuk dari beberapa unsur yaitu sistem politik, adatstiadat, agama, bahasa, pakaian, karya seni, dan karya bangunan. Namun E.B Tylor (1832-1917) berpendapat bahwa pengertian budaya atau kebudayaan adalah keseluruhan yang kompleks dan rumit di mana didalamnya terkandung ilmu pengetahuan, kepercayaan, kesenian, hukum, moral, adat, maupun kemampuan lainnya, serta kebiasaankebiasaan yang diperoleh dari manusia dalam kehidupan dan posisinya sebagai anggota masyarakat.

Begitu pun dengan Tabut merupakan unsur yang berkaitan dengan produk budaya masyarakat Kota Bengkulu yangberisikan pengetahuan, pesan, kesenian, ilmu, moral, kepercayaan, hukum, adatistiadat dan sebagai salah satu ekspresi dalam mengenang ritual matinya Husein cucu Nabi Muhammad SAW. Budaya ini hidup dan berkembang di masyarakat Kota Bengkulu serta diturunkan dari generasi ke generasi.

Fenomena sosial budaya ritual Tabut yang dimanifestasikan ke dalam bentuk seni pertunjukan dalam setiap peristiwa perayaan Tabut, biasanya digelar added event sebagai daya tarik bagi wisatawan. Aspek ritual yang semula melandasinya, pada awalnya adalah pusat dari segala upacara tradisi kini dilengkapi dengan berbagai seni tontonan atraksi budaya semacam musik dol, tari Tabut, telong-telong dan permainan ikanikan yang digelar selama perayaan Tabut, justru kini masuk ke rangkaian ritual Tabut selama 1-10 Muharam.

Kondisi di atas memunculkan gagasan dari berbagai pihak seperti seniman tradisi, para akademisi, dan tokoh masyarakat yang terlibat dalam melihat adanya fenomena bahwa seni tontonan ternyata lebih diminati masyarakat,sehingga muncul beberapa pemikiran dan ide-ide untuk mewujudkan budaya Tabut dalam bentuk garapan seni tontonan salah satunya adalah tari Tabut. Maka terbentuk sebuah tarian yang dapat dilihat dengan wujud nyata dan tampak oleh panca indra seperti gerak, penari, kostum, musik dan properti. Sebelumnya merupakan hasil pemikiran yang tak tampak oleh mata. La Ode Malim (1981: 11) mengatakan karya seni tertinggi diukur tidak saja pada artinya, melainkan juga pada wujud nyata yang tampak pada mata. 
Gagasan atau ide yang muncul bukan hanya sekadar ingin mewujudkan budaya Tabut dalam bentuk tarian. Namun juga merupakan bentuk kontribusi terhadap budaya yang telah mentradisi dengan tujuan ingin mengenalkan budaya Tabut melalui tarian. Kontribusi yang dimaksud adalah suatu hal yang dilakukan bersama-sama oleh masyarakat pendukung untuk tetap mempertahankan budaya Tabut yang sudah menjadi identitas, agar tetap lestari sesuai dengan perkembangan zaman. Langkah yang dilakukan berupa mengangkat kearifan lokal masyarakat Bengkulu yang menjadi karakteristik dan ciri khas dalam tari Tabut.

Alo Liliweri

mengatakan untuk mengetahui dan menerapkan identitas budaya, maka tidak hanya sekadar menentukan karakteristik atau ciri fisik semata, tetapi mengkaji identitas kebudayaan sekelompok manusia melalui tatanan berpikir (cara berpikir, orientasi berpikir), perasaan (cara merasa dan orientasi perasaan), dan cara bertindak (motivasi dan orientasi tindakan). Dengan mengetahui pola pikir masyarakat Bengkulu, maka akan terdapat perbedaan dan kesamaan dalam melihat budaya Tabut dari berbagai sudut pandang yang menjadi kesepakatan bersama bahwa, ini merupakan identitas masyarakat Bengkulu. Perasaan yang ingin dihadirkan dari ritual Tabut dan cara bertindak dari masyarakat Bengkulu membuat suatu bentuk nyata agar menjadi sebuah budaya yang menjadi ciri khas dan diketahui masyarakat luas. Budaya Tabut sebagai kearifan lokal masyarakat Bengkulu, diaplikasikan ke dalam berbagai gerakan tari sebagai simbol ritual Tabut yang menggambarkan kisah Husein.

Tari Tabut merupakan tari kreasi karena tari ini muncul tidak bersamaan dengan hadirnya budaya Tabut di Bengkulu. Tari Tabut muncul sejak tahun 1987, sedangkan ritual Tabut sudah ada sejak dua abad yang lalu. Prinsip tari kreasi adalah bukan geraknya harus dari tradisi tetapi tercipta dari sumber-sumber tradisi ritual Tabut. Gerak-gerak yang muncul diambil dari gerak tari tradisi Bengkulu yaitu tujuh tari dalam bimbang gedang. Jadi, ada dua sumber gerak, yaitu pertama, sumber ideologi atau idenya berasal dari ritual Tabut; kedua sumber materialnya atau idiom lokal yang berasal dari gerak tari tradisi yang ada di Bengkulu.

Tari Tabut tidak hanya sekadar menampilkan bentuk, tetapi juga menampilkan perasaan yang akan diungkapkan atau pengalaman yang diharapkan sesuai dengan tujuan upacara Tabut. Seperti diketahui, ritual Tabut merupakan ritual kepercayaan dan keagamaan. Hal itu terlihat dari proses yang dilakukan terdapat hubungan vertikal dari masyarakat Kota Bengkulu dengan sang pencipta, mengenang Husein bin Ali, kemudian kegiatan yang tak terlepas dari benda pusaka, tempat dan waktu berkaitan dengan peristiwa ritual Tabut, sebagai ungkapan kebahagiaan para pesertanya setelah bersama-sama melakukan upacara. Tari Tabut merupakan ungkapan kebersamaan, kegembiraan, kesenangan, kepuasan, dari suatu peristiwa sakral yang telah dilakukan dalam proses ritual Tabut. Sama halnya yang dikatakan I Wayan Dibia, dkk. (2006: 11),tari merupakan perwujudan ekspresi kultural atau 
budaya (nilai-nilai kolektif, termasuk keberagaman etnisitas yang ada di dalam lingkup sosialnya).

Pesatnya pengembangan zaman dapat mempengaruhi minat masyarakat terhadap tari di Bengkulu. Sehubungan dengan hal tesebut tari di daerah Bengkulu digarap dalam bentuk inovasi maupun kreativitas, sehingga menghasilkan warna baru. James Galagher mengartikan "kreativitas sebagai proses mental pada setiap individu. Melalui proses mental tersebut manusia kemudian mampu melahirkan ide serta produk baru, dan melalui adanya proses mental itu pula manusia dapat mengkombinasikan ide dengan produk yang sudah ada sebelumnya, sehingga menjadi suatu model produk yang benar-benar baru" (Tri Warta Hadi Saputra, dkk, 2019:195).

Tari Tabut sebagai sebuah manifestasi ekspresi budaya, dalam pertunjukannya melibatkan berbagai pihak. Pihak yang dimaksud seperti pemerintah daerah, budayawan, seniman tradisi dan pelaku seni. Berkat adanya peran dari berbagai pihak, maka sebuah peristiwa kesenian tersebut berjalan dengan baik. Pertunjukan tari Tabut merupakan suatu produk budaya yang kaya akan makna yang dapat dilihat dari unsurnya. Unsur yang dimaksud adalah unsur yang hadir dari dalam pola pikir, ide, ekspresi budaya Tabut yang dihadirkan ke dalam bentuk gerak. Unsur lainnya dapat dilihat dari gerak-gerak yang dihadirkan juga merupakan pengembangan tari tradisi Bengkulu serta kostum yang digunakan juga merupakan pengembangan dari pakaian adat Bengkulu. Unsur properti juga tidak lepas dari ritual Tabut dan musik yang digunakan adalah musik dol pengiring ritual Tabut. Dengan demikian, tari Tabut dapat dikatakan sebagai manifestasi budaya masyarakat Bengkulu karena tidak hanya terkandung unsur ritual Tabut, tetapi mengadung unsur budaya Bengkulu lainnya.

Tari Tabut sering ditampilkan di berbagai event di luar Kota Bengkulu. Hal ini merupakan manifestasi budaya sarat dengan misi sebagai pelestarian dan pengenalan dari apa yang sudah menjadi identitas dan kearifan lokal masyarakat Kota Bengkulu. Secara lebih luas memberi dampak positif dalam memupuk rasa cinta terhadap budaya Tabut. Dengan demikan, tari Tabut sebagai manifestasi budaya diwariskan dan dikembangkan melalui wadah seni tari yang dipertunjukkan di berbagai event baik di dalam maupun di luar Kota Bengkulu.

Tari Tabut sebagai manifestasi budaya juga dimanfaatkan sebagai daya tarik wisata terhadap pengunjung domestik dan mancanegara. Tari Tabut tidak hanya sebagai karya seni yang indah dipandang mata, tetapi juga memiliki nilai budaya Tabut. Tari ini menjadi salah satu komoditas pariwisata yang cukup potensial dan menjadi stimulus dalam pengembangan kesenian dan sanggar-sanggar yang ada di Kota Bengkulu.

\subsection{Penggambaran Tari Tabut Sebagai Manifestasi Budaya}

Sesuai dengan pendapat La Ode Malim yang menyatakan manifestasi merupakan keseluruhan diri sebagai suatu kesatuan yang utuh, yang bernilai instrinksik (membahas halhal yang dibangun di dalam karya), maka karya karya seni yang tertinggi diukur tidak saja pada artinya, 
melainkan juga pada wujud nyata yang tampak pada mata (1981 : 11).

Maka manifestasi budaya

Tabut yang diwujudkan kedalam

bentuk nyata menjadi ciri khas yang tampak pada mata seperti komponen, dapat dilihat dalam tabel berikut.

\begin{tabular}{|c|c|c|}
\hline No & Komponen & Manifestasi Budaya Tabut \\
\hline 1. & Gerak & $\begin{array}{l}\text { - Berasal dari dua sumber, pertama ideologi berasal dari } \\
\text { proses ritual Tabut yaituambik tanah, duduk penja, } \\
\text { malam menjara, meradai, arak penja, arak seroban, hari } \\
\text { gam, tabut naik pangkek, arak gedang, soja, tabut } \\
\text { tebuang, dan menyuci penja. Kedua materialnya berasal } \\
\text { dari pengembangan } 7 \text { gerak tari tradisi dalam Bimbang } \\
\text { Gedang yang ada di Bengkulu yang digarap sesuai } \\
\text { dengan kebutuhan dan keinginan koreografernya. } \\
\text { - Gerak yang dipakai dari prosesi ritual yaitu gerak } \\
\text { loncat" kedua tangan kaki secara bergantian yang } \\
\text { terdapat pada malam menjara dengan pola musik dol } \\
\text { Tamatam yang menggambarkan suasana riang (gerak } \\
\text { Uli) } \\
\text { Geraknya merupakan hasil peniruan imitasi dari } \\
\text { pengembangan gerak proses ritual Tabut yang dirubah } \\
\text { kedalam bentukgerak yang komunikatif. }\end{array}$ \\
\hline 2. & Penari & $\begin{array}{l}\text { - Merupakan tari kelompok yang dilakukan lebih dari } 2 \\
\text { orang. } \\
\text { - Penari tari Tabut pertama kali terdiri dari } 7 \text { orang } \\
\text { perempuan, dan } 7 \text { orang penari laki-laki. } \\
\text { - Seiring dengan perkembangan zaman jumlah penari tari } \\
\text { Tabut menyesuaikan kebutuhan garapan diatas pentas } \\
\text { sesuai keinginan koreografer }\end{array}$ \\
\hline 3. & Musik & $\begin{array}{l}\text { Pengembangan dari pola musik tradisi dol Tamatam } \\
\text { (untuk suasana riang dengan tempo pukulan yang } \\
\text { konstan dan ritme nya cepat), Suwena (berduka cita } \\
\text { dengan tempo pukulan lambat), Suwari (untuk } \\
\text { perjalanan panjang dengan tempo pukulan satu-satu) } \\
\text { yang menggambarkan suasana riang, berduka cita, dan } \\
\text { perjalanan panjang. } \\
\text { - Musik mengiringi gerak tari Tabut sesuai dengan situasi } \\
\text { perasaan yang dihadirkan. }\end{array}$ \\
\hline 4. & Kostum & $\begin{array}{l}\text { - Busana yang digunakan merupakan pengembangan dari } \\
\text { busana adat Bengkulu. } \\
\text { - Menggunakan baju dan celana panjang berdasarkan } \\
\text { syariat Islam. } \\
\text { - Bagian pinggang menggunakan ornamen dari rumbai } \\
\text { yang merupakan pengembangan ornamen Bengkulu } \\
\text { Pucuk Rebung. } \\
\text { - Bagian kepala menggunakan kreasi bentuk Tabut. } \\
\text { - baju laki-laki menggunakan baju melayu dan detar yang } \\
\text { - Serupakan perpaduan unsur budaya Bengkulu } \\
\text { hiasan perkembangan zaman, kreasi-kreasi baju dan } \\
\text { hiasanakin beragam dan bewarna. } \\
\end{array}$ \\
\hline 5. & Properti & - Menggunakan properti miniatur Tabut sebagai simbol \\
\hline
\end{tabular}




\begin{tabular}{|c|c|c|}
\hline & & $\begin{array}{l}\text { Tabut tempat penyimpanan potongan tubuh Husein } \\
\text { yang dijaga oleh para sahabatnya. } \\
\text { - Menggunakan properti jari-jari yang terdapat pada } \\
\text { ritual tradisi Tabut. } \\
\text { - Menggunakan coki-coki yang terdapat pada ritual Tabut. }\end{array}$ \\
\hline 6. & $\begin{array}{l}\text { Media } \\
\text { pengembangan }\end{array}$ & $\begin{array}{l}\text { - Ditampilkan pada event festival Tabut dalam lomba tari } \\
\text { kreasi Tabut setiap tahunnya. } \\
\text { - Ditampilkan dalam berbagai event di dalam maupun di } \\
\text { luar Kota Bengkulu } \\
\text { - Melalui lembaga pendidikan formal tari Tabut diajarkan } \\
\text { dalam kegiatan ekstrakulikuler di sekolah. } \\
\text { - Sedangkan dalam bentuk non formal tari Tabut hadir } \\
\text { sebagai materi yang dipelajari dan dipertunjukkan oleh } \\
\text { sanggar }\end{array}$ \\
\hline 6. & Tujuan & $\begin{array}{l}\text { - Cerminan budaya Tabut dalam bentuk tarian } \\
\text { - Mengenalkan budaya Tabut dalam bentuk tarian yang } \\
\text { bisa ditampilkan di manapun dengan durasi yang } \\
\text { singkat. } \\
\text { - Seni tontonan bersifat hiburan dan memiliki nilai } \\
\text { budaya. } \\
\text { - Tari Tabut sebagai manifestasi budaya juga sebagai daya } \\
\text { tarik wisata terhadap pengunjung baik lokal maupun } \\
\text { manca negara } \\
\text { - sebagai sebuah pengalaman yang di hadirkan ke dalam } \\
\text { bentuk tari kreasi Tabut } \\
\text { - Tari Tabut merupakan salah satu komoditas pariwisata } \\
\text { yang cukup potensial dalam pengembangan kesenian } \\
\text { dan sanggar sanggar yang ada di Kota Bengkulu. }\end{array}$ \\
\hline 7. & Manfaat & $\begin{array}{l}\text { - Ajang kreativitas dalam berkesenian terutama seni tari } \\
\text { - Komoditas pariwisata sebagai daya tarik dalam kesenian } \\
\text { - Memperkaya budaya masyarakat Kota Bengkulu } \\
\text { - Menanamkan rasa cinta terhadap budaya Tabut yang } \\
\text { - } \text { Melah mentrasdisi } \\
\text { wisatawan luar yang berguna bagi siklus kehidupan } \\
\text { warga baik dalam sektor sosial, ekonomi, religius dan } \\
\text { kepariwisataan. }\end{array}$ \\
\hline
\end{tabular}

\section{KESIMPULAN}

Manifestasi budaya merupakan aturan dalam masyarakat yang sudah kompleks atau berupa cita-cita yang sudah dirumuskan orang-orang yang arif di dalam masyarakat. Manifestasi budaya juga merupakan pola-pola tindakan yang aktual dalam suatu masyarakat. Tindakan aktual tersebut dinyatakan ke dalam bentuk sebuah produk yang telah dikemas dan dapat dilihat wujudnya. Tari Tabut sebagai Manifestasi budaya Tabut suatu prinsip yang diturunkan dari keputusan bersama masyarakat Bengkulu dalam menemukan suatu perkembangan dan cara dalam memperkenalkan budaya melalui bentuk tari yang mengadung estetika gerak dan diminati sesuai perkembangan zaman.

Tari Tabut sebagai

manifestasi budaya masyarakat 
Bengkulu merupakan hasil pola pikir mengkombinasikan ide dengan budaya tradisi Tabut yang sudah ada sebelumnya sehingga menjadi suatu model produk yang benar-benar baru. Kemudian diwujudkan kedalam berbagai gerakan tari yang geraknya merupakan pengembangan gerak tari tradisi Bengkulu dan berpijakan kepada ritus-ritus Tabut menggambarkan ritual Tabut, diperkuat oleh properti miniatur Tabut, coki-coki dan jari-jari. Tari Tabut juga merupakan seni tontonan yang mengandung nilai-nilai budaya yang cukup tinggi, karena menyuguhkan tampilan budaya Bengkulu dari yang tradisional menjadi tampilan kreasi dan modern yang lebih banyak diminati dan menarik perhatian masyarakat luas. Tari Tabut ini juga berdampak cukup signifikan bagi perkembangan budaya Bengkulu, memberi pengaruh cukup besar dalam membantu program pemerintah untuk menarik wisatawan luar yang berguna bagi siklus kehidupan warga baik dalam sektor sosial, ekonomi, religius, dan kepariwisataan.

\section{DAFTAR PUSTAKA}

Asril. (2013). Perayaan Tabuik dan Tabot: Jejak Ritual Keagamaan Islam Syiah di Pesisir Barat Sumatra. Dalam Jurnal Panggung, Vol 23. no 3.

Afriyanti, Rosi. (2019). Pitunggua Sebagai Konsep Gerak Tradisi Dalam tari Buai-Buai di Perguruan Singo Barantai Lubuak Lintah Padang. Dalam jurnal Melayu Arts and Performance Journal, Vol 2. No 2.
Dahri, Harapandi. (2009). Tabut Jejak Cinta Keluarga Nabi di Bengkulu. Bengkulu: Penerbit Citra.

Dibia, I Wayan. 2006. Tari Komunal. Jakarta: Lembaga Pendidikan Seni Nusantara.

Liliweri,Alo. (2017).Makna Budaya Dalam Komunikasi Antar Budaya.Yogyakarta: Lkis Pelangi.

Malim, La Ode. (1981). Kesenian Daerah Wolio. Jakarta: Proyek Penerbitan Buku Sastra dan Daerah.

Renta, Pesona. (2011). Tabot: Upacara Tradisi Masyarakat Pesisir Bengkulu. Dalam Jurnal Sabda, Vol 6. No 1.

Sahputra, Tri Warta Hadi, Martarosa, dan Zainal Warhat. (2019). Musik Jazz Melayu Dalam Kajian Kreativitas. Dalam Melayu Arts and Performance Journal, Vol 2. No 2.

Sepiolita, Ria Twin. (2017). Ritual Mengambik Tanah Dalam Upacara Tabut. Dalam Jurnal Seni Tari, Vol 6. No 1.

Syiafril Sy, A.(2012). Tabut Karbela Bencoolen Dari Punjab Symbol Melawan Kebiadapan. Jakarta: Walau Bengkulu. 